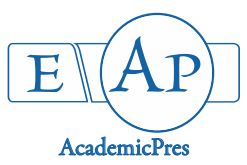

Allam A et al. (2021)

Notulae Scientia Biologicae

Volume 13, Issue 2, Article number 10921

DOI: $10.15835 / \mathrm{nsb} 13210921$

Research Article

\title{
Impact of water erosion on the properties of forest soils
}

\author{
Ayoub ALLAM ${ }^{1 *}$, Amine H. BORSALI ${ }^{1}$, Abdelkrim KEFIFA ${ }^{1}$, \\ Mohamed ZOUIDI ${ }^{2}$, Anne M. FARNET DA SILVA', \\ Catherine RÉBUFA ${ }^{3}$
}

\author{
${ }^{1}$ University of 'Dr Moulay Tahar', Laboratory of Water Resources and Environment, 20000 Saida, Algeria; \\ all-4@hotmail.fr (*corresponding author);rhizobiologie@yahoo.fri_kkefifa@yahoo.fr \\ ${ }^{2}$ Territory Planning Reseacrh Center (CRAT), Constantine; zouidibiologie20@gmail.com \\ ${ }^{3}$ Aix Marseille Université, CNRS, IRD, Avignon Université, IMBE, UMR 7263, Campus I'Etoile, 13397 Marseille, Cedex 20, \\ France; anne-marie.farnet@imbe.fr; crebufa@univ-amu.fr
}

\begin{abstract}
The research work was conducted on eroded soil in the Keroua forest of Saida, Algeria, whose objective is to know the changes in the physicochemical and biological properties of forest soils subjected to the effect of water erosion. The samples were taken to a depth between $0-10 \mathrm{~cm}$ in each zone (eroded zone and control zone). Our results show that the biological properties are the most affected by water erosion where there was a significant decrease in basal respiration and microbial biomass, which had a negative influence on the metabolic quotient (higher values in the eroded area). For chemical properties, there was an increase in organic matter and total limestone, while the $\mathrm{pH}_{\text {Water }}$ decreased in the eroded zone. For the physical properties. We raised a slight difference between the two areas, but which was not statistically significant.
\end{abstract}

Keywords: Algeria; degradation; forest; soil properties; water erosion

\section{Introduction}

The modification of natural ecosystems into agroecosystems accentuated the severity of soil erosion in the first half of the 20th century (Rémillard, 2011). Vegetation cover tends to weaken and soils are increasingly exposed to leaching and erosion, which leads to irreversibility of the situation and causing the desertification of this area (Von Hardenberg et al., 2001).

The loss of soil surface layer by water erosion has been identified as one of the major elements of soil degradation (Avakoudjo, 2015). As a result, it can negatively affect the functioning of the pores which transmit and retain water, and be a major obstacle to producing enough food to meet the demand of the growing world population (Pimentel, 2006). According to Avakoudjo (2015), the physical properties are indicators that determine the soil erosion process marked mainly by the sealing of the crust on the soil surface, soil compaction, poor drainage, hampered root growth, excessive runoff and accelerated erosion.

The effects of water erosion in forests are easily recognized. Visually, a loss of plant cover with the appearance of different forms of erosion. The intrinsic properties of the soil are not well known; therefore, it is very important to know the effects of this constraint on the properties of the soil and understand the damage

Received: 05 Mar 2021. Received in revised form: 28 Mar 2021. Accepted: 29 Apr 2021. Published online: 05 May 2021.

From Volume 13, Issue 1, 2021, Notulae Scientia Biologicae journal uses article numbers in place of the traditional method of continuous pagination through the volume. The journal will continue to appear quarterly, as before, with four annual numbers. 
caused on the fertility of forest soils. This is what justifies this study undertaken, which aims to assess the effect of water erosion on the physico-chemical and biological properties of the soil in two different sites in the Keroua forest of Saida, Algeria. Specifically, this involves comparing the properties of uneroded soil (forest soil) with eroded soil.

\section{Materials and Methods}

\section{Studyarea}

The study was carried out in the Keroua forest of Saida, Algeria, at an average altitude of $850 \mathrm{~m}$ (Figure 1). The area, being on large depressions with not very steep rock walls, where the slope is of the order of $24 \%$. However, in the affected site $\left(34^{\circ} 54^{\prime} 43.05^{\prime \prime N}\right.$; $\left.0^{\circ} 7^{\prime} 27.38^{\prime \prime} \mathrm{E}\right)$, signs of water erosion are present. On the one hand, a remarkable abundance of ravines, where the dimensions are different. Varying depths between 0.20 and $3.5 \mathrm{~m}$, and widths between 0.20 and $6 \mathrm{~m}$. on the other hand, the formation of soil slaking crust that characterize these bare soils. Their presence is accentuated by cutting of wood, and the vulnerability of the soil to erosion, due to the aggressiveness of the rains.

In terms of orographic homogeneity, the control zone located by GPS coordinates $\left(34^{\circ} 54^{\prime} 41.83\right.$ " $\mathrm{N} ; 0^{\circ}$ $7^{\prime} 22.95^{\prime \prime} \mathrm{E}$ ), has the same altitude, slope and exposure (north). This site is marked by abundant vegetation that constitutes a good canopy ensuring protection of the soil against water erosion.

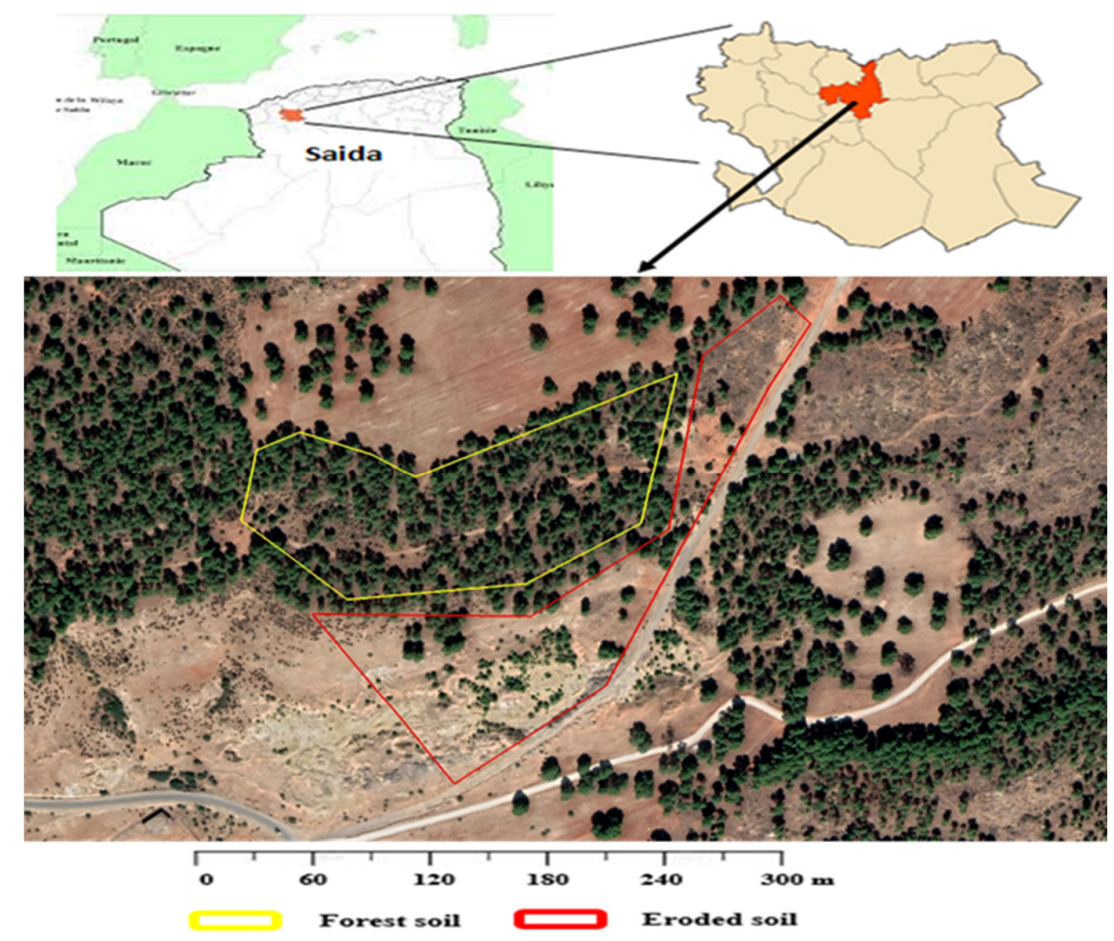

Figure 1. Location of the study area

\section{Methodology and soil sampling}

In each of the field sites (eroded zone and control zone), the depth in which the soil samples were taken is $10 \mathrm{~cm}$, were we have obtained a total of 25 samples in each zone. After removing the litter, fine roots and stones. Each soil sample was sieved to $2 \mathrm{~mm}$ and divided into two equal parts, one of which was stored instantly at $-4^{\circ} \mathrm{C}$ in order to analyse the soil microbial properties. The other part of the sample was air dried at room temperature to determine the soil physicochemical properties. 


\section{Physical analysis}

Soil moisture was estimated by the loss of mass observed after passing at $105^{\circ} \mathrm{C}$ for 24 hours (Mathieu and Pieltain, 1998). Bulk density (pv) was determined using a style ring $5 \mathrm{~cm}$ in height and $5.5 \mathrm{~cm}$ in diameter in the field (Blake and Hartge, 1986).

The principle of measurement of the real density $(\rho)$ is to determine the weight of a sample of known mass by placing it in a pycnometer under vacuum for several hours (until the air bubbles disappear) (Pétard, 1993).

Total porosity is defined as equal:

$$
p(\%)=\frac{\rho-\rho v}{\rho} \times 100
$$

For the water retention capacity. The method consists of soaking a soil sample into a beaker that contains water until it becomes saturated. After removing excess water, the sample will be dried in oven at 105 ${ }^{\circ} \mathrm{C}$ for $24 \mathrm{~h}$ (Saetre, 1998). The permeability is measured according to the protocol described by (Mathieu and Pieltain, 1998).

\section{Chemical analysis}

The $\mathrm{pH}_{\text {Water }}$ is measured in a soil suspension: water with a ratio of $1 / 2.5$ and in a solution of $1 \mathrm{~N} \mathrm{KCl}$ with the same ratio, soil salinity is measured in a liquid solution with a ratio of $1,2.5$. The calcium carbonate $\left(\mathrm{CaCO}_{3}\right)$ contents were determined by Bernard's Calcimètre. Calcination allows us to measure the organic matter in the soil. The sample is placed for 16 hours in oven at $550^{\circ} \mathrm{C}$.

\section{Biological analysis}

Basal respiration (BR) is measured by injecting of $1 \mathrm{ml}$ of the air produced by the substrate incubated for 24 hours at $23{ }^{\circ} \mathrm{C}$. The apparatus used is a chromatograph equipped with a TCD detector and a filled column (Porapack) in which helium circulates at a flux of $60 \mathrm{~mL} \cdot \mathrm{h}^{-1}$, which measures carbon dioxide (CO2) (Anderson and Domsch, 1978).

The carbon dioxide $\left(\mathrm{CO}_{2}\right)$ concentration of the vials was analysed by gas chromatography and corrected in the same way as previously described for basal respiration after incubation with a mixture of talc and glucose. Induced respiration rates were converted to microbial biomass $(\mathrm{MB})$ using the relation established by (Beare et al., 1990).

The metabolic quotient $\left(\mathrm{qCO}_{2}\right)$ is obtained as follow (Anderson and Domsch, 1978):

$$
q \mathrm{CO}_{2}=\frac{B R}{M B}
$$

\section{Statistical analysis}

The statistical software used is Minitab 17 (Minitab, LLC, company, United States). The comparison of the means between the results of the physicochemical and microbiological properties of the uneroded soil (forest soil) with an eroded soil obtained in the two zones was carried out by the student $t$-test.

\section{Results}

\section{Change in the physical properties of soils affected by water erosion}

The physical properties of the soil affected by water erosion did not change significantly ( $p>0.05)$. However, a slight difference was observed between the two zones (Table 1). Soil moisture and water retention capacity increased in soils subjected to water erosion compared to forest soil by around $0.33 \%$ and $0.8 \%$ 
respectively. For soil permeability, we recorded a decrease in the rate of infiltration by $0.09\left(\mathrm{~mm} \cdot \mathrm{h}^{-1}\right)$ in eroded soils comparing with forest soil.

Concerning soil densities, a slight decrease $\left(0.11{\mathrm{~g} . \mathrm{cm}^{-3}}^{-3}\right)$ was noted for the bulk density in the area affected by water erosion $(\mathrm{p}>0.05)$. Whereas, the real density increased by around $0.07\left(\mathrm{~g} . \mathrm{cm}^{-3}\right)$ in eroded soils $(p>0.05)$. Finally, the total porosity of the soil, which represents the ratio between these last two parameters, increased in the area subjected to water erosion compared to the forest area. This difference represents about $5.08 \%$.

\section{Change in the chemical properties of soils affected by water erosion}

The results of chemical properties show a significant decrease in $\mathrm{pH}_{\text {Water }}$ and soil organic matter in eroded soils. While for the other parameters, the difference between the two areas is not statistically significant (Table 1).

For the whole of the $\mathrm{pH}_{\text {Water }}, \mathrm{pH}_{\mathrm{KCl}}$ and electrical conductivity, the values recorded in the area subject to water erosion are low compared to the values recorded in the control area. The difference between the two zones is 0.18 for $\mathrm{pH}_{\text {Water, }} 0.12$ for $\mathrm{pH}_{\mathrm{KCl}}$ and $0.02\left(\mathrm{dS} . \mathrm{m}^{-1}\right)$ for electrical conductivity.

The soil organic matter content (eroded soil $=12.65 \%$; control $=8.49 \%$ ) and total limestone (eroded soil $=9.32 \%$; control $=3.77 \%$ ) are significantly influenced by water erosion, where there was an increase of around $4.16 \%$ and $5.55 \%$ (respectively) in the eroded area compared to their controls.

Table 1. Physico-chemical properties of control and eroded soil

\begin{tabular}{|c|c|c|c|c|}
\hline \multicolumn{2}{|r|}{ Properties } & Eroded soil & Control & Signification \\
\hline \multirow{5}{*}{ Chemical } & $\mathrm{pH}$ Water & 7.58 & 7.76 & * \\
\hline & $\mathrm{pH}_{\mathrm{KCl}}$ & 7.44 & 7.32 & NS \\
\hline & Electrical conductivity $\left(\mathrm{dS} \cdot \mathrm{m}^{-1}\right)$ & 0.24 & 0.22 & NS \\
\hline & Organic matter $(\%)$ & 12.65 & 8.49 & *** \\
\hline & Total limestone (\%) & 9.32 & 3.77 & * \\
\hline \multirow{6}{*}{ Physical } & Bulk density $\left(\mathrm{g} . \mathrm{cm}^{-3}\right)$ & 1.17 & 1.28 & NS \\
\hline & Real density $\left(\mathrm{g} . \mathrm{cm}^{-3}\right)$ & 2.49 & 2.42 & NS \\
\hline & Total porosity $(\%)$ & 51.57 & 46.47 & NS \\
\hline & Moisture (\%) & 5.48 & 5.15 & NS \\
\hline & Retention capacity (\%) & 63.20 & 62.40 & NS \\
\hline & Permeability $\left(\mathrm{cm} \cdot \mathrm{h}^{-1}\right)$ & 2.55 & 2.64 & NS \\
\hline
\end{tabular}

This table records the mean values with its significance threshold $\left({ }^{*}: \mathrm{P}<0.05 ;{ }^{* *}: \mathrm{P}<0.01 ;{ }^{* * *} ; \mathrm{P}<0.001\right.$; NS: not significant).

\section{Change in the biological properties of soils affected by water erosion}

The constraint of water erosion caused a regression in the biological properties. However, this significant

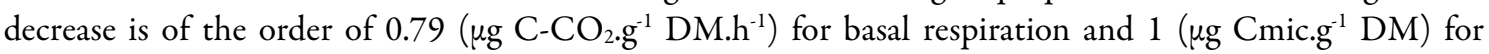
microbial biomass (Figure 2).

The metabolic quotient rates raised in the eroded areas are significantly higher than the rates of the control soils 24.5-1.95 (mg C-CO $\left.2 .(\mathrm{g} \mathrm{Cmic})^{-1} \cdot \mathrm{h}^{-1}\right)$ respectively. 
Allam A et al. (2021). Not Sci Biol 13(2):10921
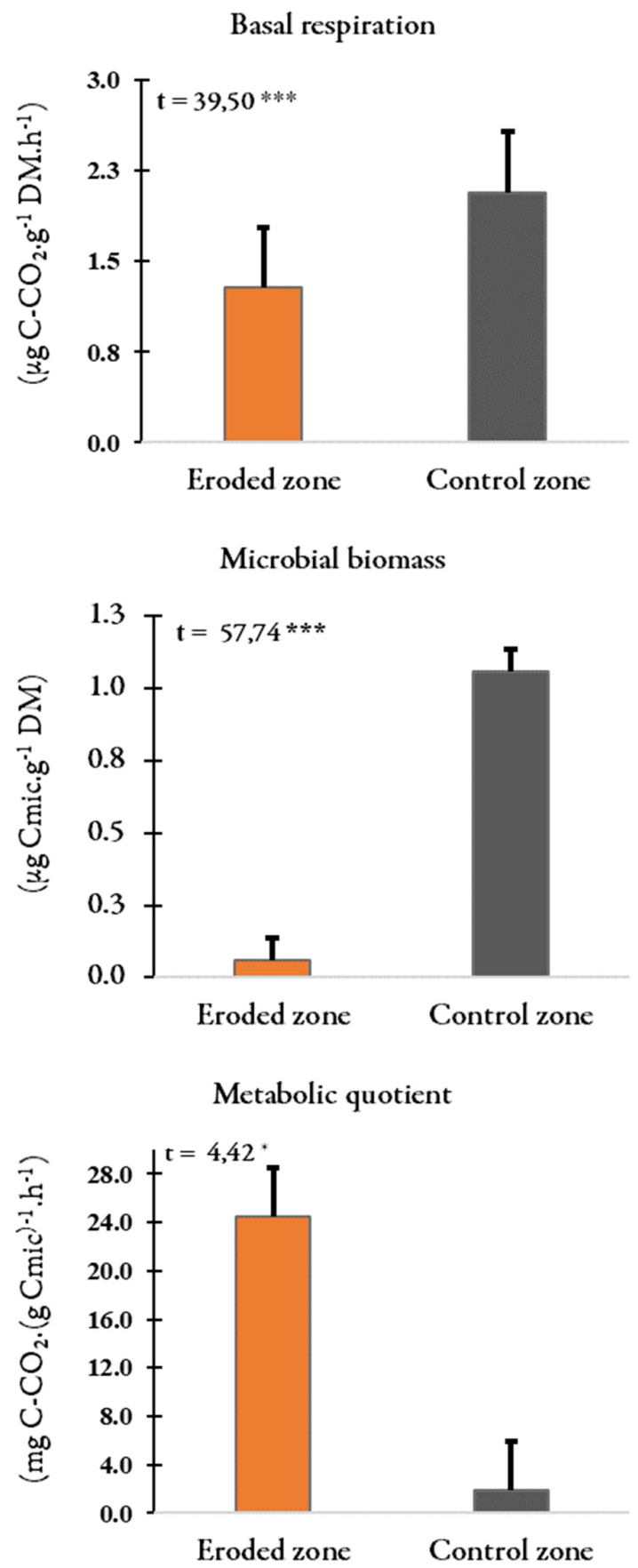

Figure 2. Variation in biological properties in eroded and control zones DM: Dry mass; Cmic: Carbon Microbial 


\section{Discussion}

Water erosion is generally known as a factor in soil degradation. For that, the studies on this constraint are numerous and their results are different as it is our case. The literature on the effects of this constraint on soil moisture seems contradictory. Some authors have found that water erosion decreases the water content in the soil, while others have found the reverse. Our results which showed that humidity is higher in soils subjected to water erosion are controversial by Nandi and Luffman (2012) who found that soil samples from erosion sites had a slightly higher moisture content than soil samples from uneroded sites (22\% and 24.54\%, respectively).

We consider that this increase is due to soil sampling in the study area which constitutes both an erosion area and a deposition area. This hypothesis is supported by Li et al. (2015), these authors, who compared the effect of water erosion in forests and adjacent edges, found higher water contents in edge soils (topographically forms a depression) than in forest soils. Likewise, water erosion in our study area reduced soil permeability. These results are supported by Vaezi et al. (2017) who concluded that, the physical properties of the soil such as permeability were strongly damaged by the impact of raindrops as the intensity of precipitation increased. According to Ramos and Pla (2003), a soil exposed to precipitation is subjected to wetting processes which can lead to the formation of a layer during precipitation, reducing infiltration and increasing erosion by increasing runoff. This decrease in permeability in soils subjected to the impact of water erosion is due to the large particles dislodged that can clog soil pores near the surface, which reduces infiltration and preventing water movement to through the soil (Wei, 2007).

Our results showed that the retention capacity of eroded soils increased slightly. This is noted by several authors, who have reported that water erosion can promote breaking aggregate, accelerate sediment transport and reduce the water retention capacity of the soil (Shi et al., 2012; Ma et al., 2014). This increase may be due to the higher rate of organic matter recorded in the eroded zone.

We recorded a decrease in bulk density and an increase in real density and total porosity. The results of Nandi and Luffman (2012) converge with our results. They concluded that the bulk density of uneroded soil is higher than the density of eroded soil, it gradually increases with depth, while in comparison, the bulk density of eroding soil was almost constant up to a depth of $50 \mathrm{~cm}$. The same authors also add that the mean porosity of the soil was higher for the eroded site (47.5\%) than for the uneroded site $(40.7 \%)$.

Our results showed that water erosion decreased $\mathrm{pH}$ water, $\mathrm{pH} \mathrm{KCl}$ and electrical conductivity. The decrease in $\mathrm{pH}_{\text {water }}$ in eroded sites has been recorded by (Zhang et al., 2006). Despite the significant difference between the two soils (eroded and control), its $\mathrm{pH}$ water remains alkaline. Wiqar (2009) found that water erosion decreases electrical conductivity in the surface layers. The values recorded in our study for the two zones (eroded and control) show that our soils are "slightly salty". The decrease in the buffering capacity of the soil and its electrical conductivity in the surface horizon is due to the downward movement of the soluble ions $\left(\mathrm{Na}^{+}, \mathrm{K}^{+}, \mathrm{Mg}^{+2} \mathrm{Cl}^{-}, \mathrm{HCO}_{-3}\right)$ with percolating water during the processes erosion and its accumulation in the lower compacted soil layers (Wiqar, 2009).

The organic matter in eroded sites has increased compared to forest sites. Our results are different from that obtained by (Vaezi et al., 2017). They have found that in areas affected by water erosion, the organic matter content of the soil has decreased due to intense rainfall and runoff. We suggest that the increase in the rate of organic matter in the soil is a direct result of the accumulation of runoff in our eroded zone where part of it constitutes a deposit zone. Water erosion disturbs the topsoil and preferentially removes organic carbon from the eroding slope and moving it to the deposition site (Lal, 2005; Dungait et al., 2013).

The rate of total limestone in soils subjected to water erosion is significantly higher than in forest soils. According to the scale proposed by Baize (1988), the forest sites present non-calcareous soils $3.27 \%\left(\mathrm{CaCO}_{3} \leq\right.$ $5 \%)$. Whereas, the eroded sites present slightly calcareous soils $9.32 \%\left(5<\mathrm{CaCO}_{3} \leq 12.5 \%\right)$. This increase can be explained by chemical eluviation due to the flow of water in the soil profile. When rains do occur, water runoff can carry sediment from upper to lower slope positions; meanwhile, it also seeps from the topsoil layer to the deeper soil layer with the eluviation of $\mathrm{CaCO}_{3}$ (Tan et al., 2008). Also, Von Wandruszka (2006) explains 
the increase of $\mathrm{CaCO}_{3}$ in the soil by the fact that the calcium carbonate molecule is easily immobilized by its adsorption and precipitation.

Our results showed that basal respiration and microbial biomass are negatively affected by the constraint of water erosion. These results are similar to those found by (Moreno-De Las Heras, 2009; Huang et al., 2013), where they showed that water erosion significantly reduced microbial abundance and their activities in the soil. According to Xiaojun et al. (2013), water erosion has negative effects on soil microbial biomass.

The quality and quantity of carbon is a more important factor influencing the biological characteristics of the soil (Li et al., 2015). This seems contradictory with our results which showed a strong decrease in basal respiration and microbial biomass in eroded soils despite its higher organic matter content. Several studies have found a positive correlation between the organic matter content of the soil and its microbial biomass and their activities (Tian et al., 2011; Zhang et al., 2011).

The redistribution of soil microorganisms induced by erosion can considerably affect the dynamics of soil carbon reservoirs through their simultaneous effects on the leaching of microorganisms, and the enrichment of the stock of organic matter in eroded soils (Wang et al., 2010). Several experimental studies have shown that the stock of organic matter in eroded soils is potentially unstable due to global disturbance (Bernoux et al., 2006). Microbial contributions to the organic matter cycle are conditioned by the interactions of microbial biomass, its community structure and soil properties (Six et al., 2006). According to Huang et al. (2013), water erosion can contribute to the redistribution of microbial communities in sloping land. A direct explanation is that, under the effect of external conditions (runoff), the topsoil, in which more microorganisms survived than in the subsoil (Fengxue et al., 2000), was eroded and transported outside the zone. As a major factor affecting the vertical and horizontal movements of microorganisms in the soil, precipitation has caused severe microbial migration to sloping soil surfaces by the action of runoff (Abu-Ashour and Lee, 2000). The water potential associated with rewetting dry soil can also kill a large number of microorganisms (Schimel et al., 1999).

The loss of most of the microbial biomass and the very low respiration in the area subjected to water erosion negatively affected the metabolic quotient. The very high rates recorded in this area confirm to us that the microbial population still remaining in the surface horizon of the soil is under stress of water erosion constraint. Noting also that, despite the amount of organic matter very abundant in these eroded soils, this microbial population has lacked the ability to use this resource to maintain their size and activities.

\section{Conclusions}

The phenomenon of water erosion, which naturally exists in all terrestrial ecosystems, has become a major problem of degradation, especially in Algerian forests.

As a result of human action, over logging has reduced wooded areas and putting the soil under the striking pressure of water erosion. The results of degradation of forest soils by water erosion have shown a significant decrease in $\mathrm{pH}_{\mathrm{H} 2 \mathrm{O}}$. Conversely, it increased the rate of organic matter and total limestone. While, for the other physicochemical properties, a slight difference was recorded between the two zones, but which is not statistically significant.

Basal respiration and microbial biomass have also been negatively affected by water erosion. The high values recorded for the metabolic quotient in the eroded zone confirmed that this constraint constitutes a stress for microorganisms in forest soils. 


\section{Authors' Contributions}

This article is part of a doctoral thesis. My thesis supervisor AHS contributed to the writing of the article and its corrections. KA ensured the statistical analysis of the results. ZM ensured the author guidelines of the article and the processing of the figures. AMFDS and CB performed the biological analysis of the soil samples. All authors read and approved the final manuscript.

\section{Acknowledgements}

We would like to thank the team Vulnerability and Conservation Ecology, Mediterranean Institute of marine and terrestrial Biodiversity and Ecology (IMBE), Aix- Marseille University, France for chemical and biological soil analyses.

\section{Conflict of Interests}

The authors declare that there are no conflicts of interest related to this article.

\section{References}

Abu-Ashour J, Lee H (2000). Transport of bacteria on sloping soil surfaces by runoff. Environmental Toxicology: An International Journal 15(2):149-153. https://doi.org/10.1002/(SICI)1522-7278(2000)15:2<149::AIDTOX11>3.0.CO;2-O

Anderson JP, Domsch KH (1978). A physiological method for the quantitative measurement of microbial biomass in soils. Soil Biology and Biochemistry 10(3):215-221._https://doi.org/10.1016/0038-0717(78)90099-8

Avakoudjo J, Kouelo AF, Kindomihou V, Ambouta K, Sinsin B (2015). Effet de l'érosion hydrique sur les caractéristiques physicochimiques du sol des zones d'érosion (dongas) dans la Commune de Karimama au Bénin [Effect of water erosion on the physicochemical characteristics of the soil in erosion zones (dongas) in the Municipality of Karimama in Benin]. Agronomie Africaine 27(2):127-143. https://www.ajol.info/index.php/aga/article/view/125523

Baize D (1988). Guide des analyses courantes en pédologie. [Guide to current analyzes in pedology]. Ed. INRA, Paris, pp 171.

Beare MH, Neely CL, Coleman DC, Hargrove WL (1990). A substrate-induced respiration (SIR) method for measurement of fungal and bacterial biomass on plant residues. Soil Biology and Biochemistry 22(5):585-594. https://doi.org/10.1016/0038-0717(90)90002-H

Bernoux M, Cerri CC, Cerri CEP, Siqueira Neto M, Metay A, Perrin AS, ... Milne E (2006). Cropping systems, carbon sequestration and erosion in Brazil, a review. Agronomy for Sustainable Development 26:1-8. https://doi.org/10.1051/agro:2005055

Blake GR, Hartge KH (1986). Bulk density. In: Klute A (Ed). Methods of Soil Analysis: Part I. Physical and Mineralogical Methods, 2nd ed. American Society of Agronomy, Soil Science Society of America, Madison, WI, pp 363-382.

Dungait JA, Ghee C, Rowan JS, McKenzie BM, Hawes C, Dixon ER, ... Hopkins DW (2013). Microbial responses to the erosional redistribution of soil organic carbon in arable fields. Soil Biology and Biochemistry 60:195-201. https://doi.org/10.1016/j.soilbio.2013.01.027

Fengxue G, Borong P, Qikai W, Yusuo Y (2000). A preliminary study on soil microorganisms of artificial vegetation in the center of Taklimakan Desert. Biodiversity Science 8(3):297-303. https://doi.org/10.17520/biods.2000041

Huang J, Li Z, Zeng G, Zhang J, Li J, Nie X, Ma W, Zhang X (2013). Microbial responses to simulated water erosion in relation to organic carbon dynamics on a hilly cropland in subtropical China. Ecological Engineering 60:67-75. https://doi.org/10.1016/j.ecoleng.2013.07.040 
Allam A et al. (2021). Not Sci Biol 13(2):10921

Lal R (2005). Soil erosion and carbon dynamics. Soil and Tillage Research 81(2):137-142. https://doi.org/10.1016/j.still.2004.09.002

Li Z, Xiao H, Tang Z, Huang J, Nie X, Huang B, ... Zeng G (2015). Microbial responses to erosion-induced soil physicochemical property changes in the hilly red soil region of southern China. European Journal of Soil Biology 71:3744. https://doi.org/10.1016/j.ejsobi.2015.10.003

Ma W, Li Z, Ding K, Huang J, Nie X, Zeng G, Wang S, Liu G (2014). Effect of soil erosion on dissolved organic carbon redistribution in subtropical red soil under rainfall simulation. Geomorphology 226:217-225. https://doi.org/10.1016/j.geomorph.2014.08.017

Mathieu C, Pieltain F (1998). Analyse physique des sols. Methodes choisies. [Physical analysis of soils. Chosen methods]. Research Institute for Development, Paris: Lavoisier, pp 275.

Moreno-De Las Heras M (2009). Development of soil physical structure and biological functionality in mining spoils affected by soil erosion in a Mediterranean-Continental environment. Geoderma 149(3-4):249-256. https://doi.org/10.1016/j.geoderma.2008.12.003

Nandi A, Luffman I (2012). Erosion related changes to physicochemical properties of Ultisols distributed on calcareous sedimentary rocks. Journal of Sustainable Development 5(8):52-68. https://doi.org/10.5539/jsd.v5n8p52

Petard J (1993). Les méthodes d'analyses. [Methods of analysis (volume 1)]. ORSTOM 5:192.

Pimentel D (2006). Soil erosion: a food and environmental threat. Environment, Development and Sustainability 8(1):119-137. https://doi.org/10.1007/s10668-005-1262-8

Ramos MC, Nacci S, Pla I (2003). Effect of raindrop impact and its relationship with aggregate stability to different disaggregation forces. Catena 53(4):365-376. https://doi.org/10.1016/S0341-8162(03)00086-9.

Rémillard S (2011). Pampa argentine solutions face à la désertification d'une écorégion [Pampa argentina: solutions to the desertification of an ecoregion]. Doctoral thesis, University of Sherbrooke, Québec, Canada, pp 93.

Saetre P (1998). Decomposition, microbial community structure, and earthworm effects along a birch-spruce soil gradient. Ecology 79(3):834-846. https://doi.org/10.1890/0012-9658(1998)079[0834:DMCSAE]2.0.CO;2

Schimel JP, Gulledge JM, Clein-Curley JS, Lindstrom JE, Braddock JF (1999). Moisture effects on microbial activity and community structure in decomposing birch litter in the Alaskan taiga. Soil Biology and Biochemistry 31(6):831838. https://doi.org/10.1016/S0038-0717(98)00182-5

Shi ZH, Fang NF, Wu FZ, Wang L, Yue BJ, Wu GL (2012). Soil erosion processes and sediment sorting associated with transport mechanisms on steep slopes. Journal of Hydrology 454:123-130. https://doi.org/10.1016/j.jhydrol.2012.06.004

Six J, Frey SD, Thiet RK, Batten KM (2006). Bacterial and fungal contributions to carbon sequestration in agroecosystems. Soil Science Society of America Journal 70(2):555569. _https://doi.org/10.2136/sssaj2004.0347

Tan LP, He XD, Wang HT, Zhang N, Gao YB (2008). Analysis of soil water content in relation to accumulation of pedogenic calcium carbonate of Artemisia ordosica community in Tengger Desert. Journal of Desert Research 28:701-705.

Tian J, McCormack L, Wang J, Guo D, Wang Q, Zhang X, ... Kuzyakov, Y (2015). Linkages between the soil organic matter fractions and the microbial metabolic functional diversity within a broad-leaved Korean pine forest. European Journal of Soil Biology 66:57-64. https://doi.org/10.1016/j.ejsobi.2014.12.001

Vaezi AR, Ahmadi M, Cerdà A (2017). Contribution of raindrop impact to the change of soil physical properties and water erosion under semi-arid rainfalls. Science of the Total Environment 583:382-392. https://doi.org/10.1016/j.scitotenv.2017.01.078

Von Hardenberg J, Meron E, Shachak M, Zarmi Y (2001). Diversity of vegetation patterns and desertification. Physical Review Letters 87(19):198101. https://doi.org/10.1103/PhysRevLett.87.198101

Von Wandruszka R (2006). Phosphorus retention in calcareous soils and the effect of organic matter on its mobility. Geochemical Transactions 7(1):1-8. https://doi.org/10.1186/1467-4866-7-6

Wang Z, Govers G, Steegen A, Clymans W, Van den Putte A, Langhans C, ... Van Oost K (2010). Soil carbon redistribution by water erosion at the catchment level in an intensively cultivated area: characteristics, budgets and implications. In: EGU General Assembly Conference Abstracts 2010, 2-7 May, 2010, Vienna, Austria, Vol 12, pp 1796.

Wei L, Zhang B, Wang M (2007). Effects of antecedent soil moisture on runoff and soil erosion in alley cropping systems. Agricultural Water Management 94(1-3):54-62. https://doi.org/10.1016/j.agwat.2007.08.007 
Wiqar A (2009). Managing soil fertility for sustained crop productivity on eroded lands of District Swabi. Doctoral thesis, Department of Soil and Environmental Sciences, Agricultural University, Peshawar, pp 161-169.

Xiaojun N, Jianhui Z, Zhengan S (2013). Dynamics of soil organic carbon and microbial biomass carbon in relation to water erosion and tillage erosion. PLoS One 8(5):e64059. https://doi.org/10.1371/journal.pone.0064059

Zhang J, Quine TA, Ni S, Ge F (2006). Stocks and dynamics of SOC in relation to soil redistribution by water and tillage erosion. Global Change Biology 12(10):1834-1841. https://doi.org/10.1111/j.1365-2486.2006.01206.X

Zhang J, Zeng G, Chen Y, Yu M, Yu Z, Li H, ... Huang H (2011). Effects of physico-chemical parameters on the bacterial and fungal communities during agricultural waste composting. Bioresource Technology 102(3):2950-2956. https://doi.org/10.1016/j.biortech.2010.11.089
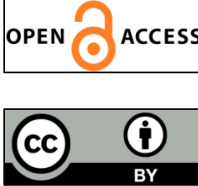

The journal offers free, immediate, and unrestricted access to peer-reviewed research and scholarly work. Users are allowed to read, download, copy, distribute, print, search, or link to the full texts of the articles, or use them for any other lawful purpose, without asking prior permission from the publisher or the author.

License - Articles published in Notulae Scientia Biologicae are Open-Access, distributed under the terms and conditions of the Creative Commons Attribution (CC BY 4.0) License.

(c) Articles by the authors; SHST, Cluj-Napoca, Romania. The journal allows the author(s) to hold the copyright/to retain publishing rights without restriction. 